\title{
Career management attitudes among business undergraduates
}

\section{AUSTRALIAN JOURNAL OF CAREER DEVELOPMENT}

Jackson, $\mathrm{D}^{1}$. and Wilton, $\mathrm{N}^{2}$.

\begin{abstract}
Globalisation, organisational restructuring and new technology have been connected with a shift to 'protean' and 'boundaryless' career attitudes with workers, including new graduates increasingly required to be self-reliant in successfully navigating their careers. This study explores protean and boundaryless career attitudes among Business undergraduates and the influence of demographic, background, and employment characteristics on these attitudes. Data were collected for Business undergraduates at a UK $(N=88)$ and Australian university $(N=284)$. Results indicate the students score more highly, on average, in the self-direction and boundaryless mindset dimensions. Relatively lower mean scores for physical mobility and values-driven suggests a 'one high, one low' pattern among the two items that constitute protean and boundaryless career attitudes. Employment status and Business degree specialisation were found to significantly predict career attitudes. Findings develop our understanding of whether emerging professionals are equipped to effectively self-manage their careers and implications for educators and professional practitioners are discussed.
\end{abstract}

\section{Keywords}

Career management, graduate, protean, boundaryless, career attitudes.

\footnotetext{
${ }^{1}$ Edith Cowan University, Australia

${ }^{2}$ UWE Bristol
} 
A range of both recent and long-term trends associated with the labour markets of developed economies have been connected with a shift in the attitudes associated with successful career self-management. The globalisation of labour markets, the restructuring of organisations and internal labour markets and the rapid development and diffusion of new technology have had far reaching implications for the experience of work, jobs and careers. This new world of work has created both new opportunities for career self-management as well as significant employment insecurity and risk (Grote \& Raeder, 2009). While the full impact of these shifts on careers is contested (Baruch, 2006; Inkson, Gunz, Ganesh \& Roper, 2012), and undoubtedly varies between contexts and occupational group (Pringle \& Mallon, 2003), changes to the nature of work, and employment have widely been associated with a weakening relationship between employer and employee (Bennett, Pitt \& Price, 2012) and a shift in responsibility for career management from the organisation to individual (Clarke \& Patrickson, 2008).

Allied to the blurring of work/life boundaries (Sturges, 2008) and the shift in focus to careers that develop outside of clear boundaries (Inkson, 2006), workers are now expected to develop a range of career management capabilities and attitudes. Individuals are required to become self-reliant in managing their careers and self-reflective about motives and capabilities. They are expected to assume greater ownership of career development and to acquire and to develop a demonstrable set of portable skills and knowledge which fosters adaptability in any environment (O'Connell, McNeely \& Hall, 2008). Savickas (1997) emphasises the importance of developing career adaptability, described as "the readiness to cope with ... the unpredictable adjustments prompted by changes in work and working conditions" (p. 254), through exploring oneself and the environment, career planning, and decision-making. Many workers, including graduates entering the labour market, are 
therefore expected to be able to successfully navigate their career across endless possibilities (Briscoe \& Hall, 2006). This is deemed particularly important during periods of economic uncertainty (Briscoe, Henagan, Burton \& Murphy, 2012), apparent in many developed countries post-GFC.

Associated with the dominant discourse of the 'death of career' and the evolution of new deals in employment (Adamson, Doherty \& Viney, 1998), in the past two decades these new careers have been variously conceptualised and labelled as 'boundaryless' (Arthur, 1994), 'protean' (Hall,1996), ‘free-form' (Leach \& Chakiris, 1998), 'post-corporate' (Pepeirl \& Baruch, 1997), and 'multi-directional' (Baruch, 2004). Whilst distinctive in emphasis, these conceptualisations offer variations on a theme whereby the new career is contrasted with the 'traditional' career associated with structured and status-oriented career progression and have dominated the recent literature on career attitudes (see Clarke, 2009). These new career types necessitate the adoption and development of commensurate orientations by workers. For instance, a protean career orientation is concerned with self-invention, autonomy and self-direction (Hall, 2002). It is characterised by a 'values driven' approach (Briscoe \& Hall, 2006) where internal principles and attitudes motivate and guide career decisions, rather than extrinsic factors such as pay. The degree to which an individual internalises such an approach to career management reflects the extent to which they possess a protean career orientation (see Segers et al., 2008) and, consequently, how adept they are likely to be at navigating the new context of careers. The notion of the boundaryless career is associated with both 'physical mobility' (Sullivan \& Arthur, 2006), across organisations, occupations, and geography, and a 'boundaryless mindset', described by Briscoe, Hall \& DeMuth (2006) as individual capacity for "initiating and pursuing work-related relationships across organizational boundaries" (p. 31). This dimension focuses on the degree to which 
individuals can manage psychological boundaries such as work/life balance and advance their perceived marketability.

This paper explores the career attitudes among undergraduate students in the UK and Australia. Pringle and Mallon (2003) suggest that new career forms are most applicable to professional and managerial occupations and, therefore, have particular resonance for graduates who are most likely to enter such professions. Moreover, given contemporary patterns of youth unemployment and underemployment (GCA, 2012; Purcell et al., 2013) in many developed economies and an increasingly competitive and volatile graduate labour market, the adoption of the flexible mindset associated with new career forms would seem critical for recent and future graduates. Deepening our understanding of career attitudes among contemporary undergraduates will inform both employers and Higher Education Institutions (HEI) in developing appropriate strategies to ensure emerging professionals are equipped with the attributes necessary for career success.

Specifically, this paper: (i) explores the adoption of protean and boundaryless attitudes to career management; (ii) examines the relationships among protean and boundaryless attitudes to career management; and (iii) identifies variations in career attitudes by demographic, background and/or employment characteristics. The research objectives are addressed by exploring career attitudes among Business undergraduates, in the UK and Australia. The paper is structured to first provide a background review of literature relating to career management attitudes and the influential role of individual characteristics. Second, the study's methodology is outlined, followed by a summary of results, based on descriptive and hierarchical multiple regression analyses. Findings and the implications for education and 
human resource practitioners are discussed and, finally, the limitations and directions for future research set out.

\section{Background}

\section{Protean and boundaryless career attitudes.}

While acknowledging debates regarding the extent to which the career landscape is 'all change' (Baruch, 2006), it is inarguable that there has been a significant shift in the responsibility for one's career from the organisation to self. This is recognised in the boundaryless and protean career concepts which focus on individual career self-management and personal responsibility for the continuous development of one's employability (de Vos, Dewettinck \& Buyens, 2009). The extent of career self-management is defined by King (2004) as "the degree to which one regularly gathers information and plans for career problem solving and decision making" (p. 3) and encompasses activity in seeking opportunities, strategic networking and labour market awareness (Sturges et al., 2005). In contrast, organisational career management involves assisting employees in developing career pathways though internal hierarchies, structures and functions, using initiatives and programs such as mentoring, training, counselling, and project working (King, 2004). Whatever the extent and formality, organisational career management and individual career management are intricately entwined and together influence both individual career success and organisational commitment (see de Vos et al., 2009). The limitation of organisational career management in assisting employees in following career trajectories beyond the organisation, in combination with wider changes to the experience of work and employment, has led to greater focus on the development of boundaryless and protean career attitudes. Some commentators believe these contemporary career orientations substitute more traditional ones (Baruch, 2006) yet evidence suggests that the traditional career remains entrenched among workers (Currie, Tempest \& Starkey, 2006). 
Despite the significant attention paid to career change in recent years, Jain and Jain (2013) argue career attitudes remain relatively underexplored. This represents a notable deficit in research as, for individuals, awareness of one's own career orientation is important for making informed career decisions and, for recruiters, appreciation of both individual and pervasive career orientation is critical for the effective recruitment, management and retention of talent (Segers et al., 2008). Career attitudes have been shown to be both the product of a range of individual attributes and an influential factor in shaping labour market behaviour and achievement (see, for example, Herrmann, Hirschi \& Baruch, 2015). Protean attitudes augment identity awareness, better equipping individuals to manage change (Briscoe et al., 2012), and career success (Park, 2009). Boundaryless attitudes encourage individuals to seek support and opportunities beyond their current workplace, can lead to active coping and well-being (Briscoe et al., 2012) and are linked to career success (Inkson, 2006).

In respect of the protean career orientation, Briscoe and Hall (2006) argue the degree to which an individual displays the constituent dimensions of 'self-directedness' and 'values driven' will result in four different career orientations. First, individuals whose values have little influence on their career decisions and which demonstrate little self-directedness are considered 'dependant'. Those who self-manage their careers but are not directed by internal values, instead placing emphasis on external rewards, are considered 'reactive'. A lack of self-directedness combined with motivation by values will result in a 'rigid' orientation which implies individuals will not be able to shape their career pathways. Finally, the 'protean' orientation will result from individuals demonstrating both dimensions. Sullivan and Arthur (2006) also define quadrants for the different ways an individual may be positioned on the boundaryless orientation continua, depending on the degree to which they 
demonstrate the two constituent dimensions of 'boundaryless mindset' and 'physical mobility'. Eby et al. (2003) also argue 'knowing why', 'knowing whom' and 'knowing how' will determine the degree to which one will succeed in the boundaryless career, stressing the importance of networking and relationship-building, the portability and marketability of one's human capital and self-knowledge and one's sense of personal identity (Arthur, 1994).

Briscoe and Hall (2006) combine the four underlying dimensions of protean and boundaryless career attitudes to produce 16 possible career orientations (see Segers et al., 2008 for a detailed discussion of these profiles). Segers et al. argue an individual's position on the protean and boundaryless continua will influence what motivates them at work and will have implications for how to manage effectively individuals with different orientations. Self-directed individuals require challenging assignments and opportunities for personal growth and organisations should implement initiatives which facilitate the discussion and negotiation of career pathways aligned with personal values, rather than simply offering extrinsic rewards. For the boundaryless career orientation, those with high physical mobility seek positions and opportunities which have high rewards and are less concerned with job security while those demonstrating the boundaryless mindset require autonomy and scope for developing diverse networks.

\section{Career attitudes among undergraduates.}

Jain and Jain (2013) suggest that new graduates correspond to the exploration stage of Cron's (1984) four career stages: exploration, establishment, maintenance and disengagement. They argue new graduates' attitudes are transferred from their university experience and will affect job performance during this and the establishment stages. The development of positive and helpful career attitudes during academic study is therefore 
critical for short and long-term career success and organisational performance. That said, while prior studies have shown a correlation between the adoption of Protean and boundaryless mindsets and career success, evidence also suggested there are attendant risks associated with such orientations. Verbruggen (2012) found that although a boundaryless mindset was positively associated with high wages and more promotion, organisational mobility preference led to fewer promotions, lower job satisfaction and lower career satisfaction among Business graduates. This is perhaps a reflection of the reality of contemporary careers where the benefits of new career forms are realised for some but not others, despite adoption of commensurate attitudes. Such careers have been found to result in a trade-off between subjective and objective career success (Cohen \& Mallon, 1999) and that there is inevitable accretion of risk associated with the transference of career responsibility from employer to employee (Grote \& Raeder, 2009). In other words, the adoption of attitudes commensurate with new career forms does not lead to universally positive outcomes. Consequently, HEIs appear to have an additional responsibility of ensuring students are cognisant of the challenges of the contemporary labour market and are sufficiently flexible and resilient in their outlook to cope with both complexity and change.

King $(2003 ; 2004)$ argues it is younger and more highly skilled workers who have internalised messages about the decline of traditional careers. It could, therefore, be assumed the adoption of protean or boundaryless orientations is most vital, and also more likely, among those entering initial employment post-graduation. However, evidence (King, 2003; Sturges, Conway, Guest \& Liefooghe, 2005) also suggests that many graduates, while paying lip service to the notion of the new career, held attitudes more aligned with conventional career development and high expectations of organisational career management. 
Briscoe et al. (2006) found variations across the four dimensions relating to protean and boundaryless career attitudes by career stage (namely undergraduates, MBAs and executives) and context. To them, this suggested that the dimensions reflect attitudes that are malleable and could be taught and developed. Their data demonstrated a 'high-low' phenomenon for all three samples whereby a higher mean rating for self-direction and a lower mean rating for values-driven within the protean orientation was reported. According to Briscoe and Hall (2006), individuals with high self-direction and low values-driven are 'reactive' and manage their careers but let organisational values, rather than internal ones, guide their decisions. For boundaryless attitudes, Briscoe and colleagues also reported a 'high-low' pattern with a higher mean rating for boundaryless mindset and a lower mean rating for physical mobility. This is categorised by Sullivan and Arthur (2006) as individuals belonging to 'quadrant three' whom "sustain high expectations of their own employability ... without changing employers" (p. 24). Subsequently, this discussion leads to the following hypotheses:

Hypothosis 1a: Average ratings for self-direction will be relatively higher than values-driven among Business undergraduates.

Hypothesis 1b: Average ratings for boundaryless mindset will be relatively higher than physical mobility among Business undergraduates.

\section{Relationship among protean and boundaryless career attitudes.}

Often considered interchangeable, protean and boundaryless career orientations are distinct and influence behaviour in different ways (see Segers et al., 2008). They both encapsulate, however, the notion that contemporary career self-management no longer simply concerns vertical advancement within a single or limited set of employers but navigating more complex and less stable career pathways. These routes often cross cultural, 
organisational and national boundaries (Tams \& Arthur, 2007), requiring the development and exploitation of strategic relationships and networks in order to realise personal needs and expectations (Eby, Butts \& Lockwood, 2003). Briscoe et al. (2006) also assert the distinct nature of the different dimensions of career attitudes, arguing an individual could demonstrate boundaryless attitudes yet expect and rely on their organisation to cultivate their career. They believed the relationship among career attitudes would vary with work context and this was confirmed in their study of undergraduates, MBA students and management executives which reported different relationships among the four dimensions. Briscoe and colleagues found some evidence of a lack of relationship between physical mobility and the other three dimensions in the undergraduate sample, attributing this to their relative inexperience and lack of desire to explore the unknown. They reported a significant relationship between the two protean dimensions and also a correlation between both and boundaryless mindset. As a result, the following hypotheses have been developed:

Hypothosis 2a: Self-direction and values driven are positively associated among Business undergraduates.

Hypothesis 2b: Self-direction and boundaryless mindset are positively associated among Business undergraduates.

Hypothesis 2c: Values-driven and boundaryless mindset are positively associated among Business undergraduates.

Hypothesis 2d: Physical mobility is not associated with boundaryless mindset or protean career attitudes among Business undergraduates.

\section{Influence of individual characteristics.}

There are a broad range of antecedents of career orientation and attitudes, including career stage and preference for mobility (Briscoe \& Finkelstein, 2009), socio-economic status 
(Greenbank, 2011), cultural context (Sullivan \& Arthur, 2006), personality (Creed, Macpherson \& Hood, 2011), and industry sector (Schneider, Smith, Taylor \& Fleenor, 1998). Interpreting where an individual is positioned on the boundaryless and protean career continua requires, however, an understanding of their demographic and background characteristics (Gerber, Wittekind, Grote \& Staffelbach, 2009). Age is broadly considered to be positively related to the values driven dimension with the more mature being motivated by societal values and guided by a moral compass (see Briscoe et al., 2006; Segers et al., 2008). The relationship between self-direction and age is less clear. Some assert individuals are less driven to adapt and self-develop as they age, advocating a negative association (see Segers et al., 2008). In Briscoe et al.'s study, a slight positive effect was recorded between selfdirection and age for the undergraduate, MBA and executive samples. This, however, may be attributed to the documented positive association between education level and career attitudes (Gerber et al., 2009; see Segers et al., 2008). Given this study's sample are all participating in undergraduate study, and their enrolment has demonstrated an element of self-direction irrespective of their age and circumstances, it is projected there will be no association between age and self-direction. Accordingly:

Hypothesis 3a: Age is not associated with self-direction among Business undergraduates.

Hypothesis 3b: Age is positively associated with values-driven attitudes among Business undergraduates.

In relation to the boundaryless career, Segers et al. (2008) found no evidence to support the assertion that boundaryless mindset increases with age. Briscoe et al.'s (2006) slight positive effect among undergraduates, MBAs and executives could, again, be attributed to education level. While a negative association between age and physical mobility has been reported (see Segers et al., 2008), current pressure on new graduates to be flexible and 'go 
where the work is' in tough economic conditions could pre-empt similar mobility preferences among all ages. This leads to the following hypothesis:

Hypothesis 3c: Age is not associated with boundaryless career attitudes among Business undergraduates.

Many believe gender is unrelated to career attitudes (Hall, 2004) and Briscoe et al. (2006) did not detect a gender effect for any of the four attitude dimensions. For the protean orientation, support for gender variation in self-directedness is absent in previous studies (see Segers et al., 2008). While there is some evidence to suggest females are more values-driven (Mainiero \& Sullivan, 2005), findings are not always consistent and variations may apply to those more advanced in their careers. There is some evidence suggesting lower levels of physical mobility among females (Segers et al., 2008; Sullivan \& Arthur, 2006) due to concerns for work/life balance, fewer opportunities and supporting their partner's career (Forett et al., 2010). Men are also reported to have lower psychological mobility due to following a linear career pathway with little room for career exploration, associated with conformity to societal expectations of their role as breadwinner (Forett et al., 2010). Given the mixed evidence, early career stage of the sample, and prevalent economic uncertainty which may generate heightened flexibility among undergraduates, we do not expect an association between boundaryless attitudes and gender. This discussion leads to:

Hypothesis 4a: Gender is not associated with protean career attitudes among Business undergraduates.

Hypothesis 4b: Gender is not associated with boundaryless career attitudes among Business undergraduates. 
Employment background is also deemed influential, including organisational tenure (Gerber et al., 2009; Mathieu \& Zajac, 1990), industry sector (Segers et al. 2008) and number of years of full-time working, number of employers, and number of voluntary job changes (Briscoe et al., 2006). Gerber and colleageues found employment status produced different career attitudes with those in full-time work, in contrast to those working part-time, being more independent in orientation. They define an independent career orientation as "a positive attitude towards frequent changes of organizations and also, commitment to oneself rather than the employer" (p. 3). This suggests that those with greater exposure to working will adopt more protean and boundaryless attitudes to career management, leading to the following hypotheses:

Hypothesis 5a: Employment status is positively associated with protean career attitudes among Business undergraduates.

Hypothesis 5b: Employment status is positively associated with boundaryless career attitudes among Business undergraduates.

While specialisation is limited to within the field of Business, this has produced variations in career management competency (Kuijpers \& Meijers, 2012), and both short- and long-term employment outcomes for graduates (Wilton, 2012). Further, variations in the labour market trends for different Business specialisations exist (see GCA, 2015) and may also influence attitudes to career management. As Li and Miller (2013) assert, "it is what graduates studied, rather than where they graduated from, which made a large difference in their labour market outcomes" (p. 25). It has been included in our analysis to contribute to a more nuanced understanding of career decision-making that might ultimately influence labour market experience and achievement. Certain specialisations may nurture a more independent attitude to career management and accentuate the importance of social values 
rather than instrumental motivators for career success. Some may also highlighted the broad range of employment contexts for that particular field and the importance of being open and able to navigate different trajectories for career success. Accordingly:

Hypothesis 6a: Protean career attitudes among Business undergraduates will vary by degree specialisation.

Hypothesis 6b: Boundaryless career attitudes among Business undergraduates will vary by degree specialisation.

\section{Method}

\section{Participants.}

Second and third year Business undergraduates studying at a UK $(N=88)$ and an Australian university $(N=284)$ participated in the study. Both universities are vocationallyfocused with an emphasis on quality teaching and learning at both undergraduate and postgraduate levels. Although the universities are situated in different labour market contexts, these have similar labour market conditions at the time of the survey. Both experienced high levels of graduate unemployment and underemployment (GCA, 2014; UKCES, 2015) and economic uncertainty. The cross-national focus of the study may develop our understanding of career attitudes within broader contexts and the impact of demographic, background and employment characteristics among countries with similar labour market contexts.

Table 1 summarises the characteristics for both university samples. A prerequisite for participation was employment within the previous 12 months or completion of a work placement/internship as part of their undergraduate degree studies, ensuring respondents had the experience necessary to confidently gauge their career attitudes. The average age of the Australian sample was 26 years; the UK sample 21 years and, overall, 25 years. The 
associated standard deviations were 7.69, 2.63 and 7.09 respectively and mean ages between the two samples differed significantly $(p=.000)$. The Australian sample comprises a relatively high number of mature-age students, reflecting the range of different entry pathways encouraged at the university. The higher proportion of females is a reasonable representation of student enrolments at both universities. In relation to discipline, there are considerably more Australian students specialising in the Finance and Tourism groupings, counterbalanced by more specialising in Marketing and completing generalist Business degrees in the UK. The distribution of students across employment status was not dissimilar for the two samples yet differences were apparent for stage of degree with relatively more third year students from the UK university. Greater numbers meeting the required work experience prerequisite may explain the higher response rate in Australia.

\section{Procedures.}

Participation in the study required the completion of an online survey. Business undergraduates were invited to participate in the study through announcements, in addition to direct emails, via the respective universities' virtual learning environment. Data was gathered over a three-month period between May and July 2014. The survey response rate is difficult to gauge, given a lack of information regarding the extent of work experience among the population. 
Table 1 Summary of participants by institution

\begin{tabular}{|c|c|c|c|c|c|c|c|}
\hline \multirow[b]{2}{*}{ Variable } & \multirow[b]{2}{*}{ Sub-group } & \multicolumn{2}{|c|}{ Australia $(N=284)$} & \multicolumn{2}{|c|}{ UK $(N=88)$} & \multicolumn{2}{|c|}{$\begin{array}{r}\text { Total }(N=372) \\
\text { Valid }\end{array}$} \\
\hline & & $\mathbf{N}$ & Valid \% & $\mathbf{N}$ & Valid \% & $\mathbf{N}$ & $\%$ \\
\hline \multirow[t]{2}{*}{ Gender } & Male (0) & 84 & $29.6 \%$ & 36 & $40.9 \%$ & 120 & $32.3 \%$ \\
\hline & Female & 200 & $70.4 \%$ & 52 & $59.1 \%$ & 252 & $67.7 \%$ \\
\hline \multirow[t]{7}{*}{ Specialisation } & Finance/Accounting (0) & 87 & $30.6 \%$ & 7 & $8.0 \%$ & 94 & $25.3 \%$ \\
\hline & $\begin{array}{l}\text { Tourism, Hospitality, } \\
\text { Recreation and Events }\end{array}$ & 41 & $14.4 \%$ & 0 & $0.0 \%$ & 41 & $11.0 \%$ \\
\hline & $\begin{array}{c}\text { Marketing, Public Relations } \\
\text { and Advertising }\end{array}$ & 39 & $13.7 \%$ & 27 & $30.7 \%$ & 66 & $17.7 \%$ \\
\hline & $\begin{array}{c}\text { Human Resource } \\
\text { Management }\end{array}$ & 47 & $16.5 \%$ & 5 & $5.7 \%$ & 52 & $14.0 \%$ \\
\hline & Generalist & 27 & $9.5 \%$ & 26 & $29.5 \%$ & 53 & $14.2 \%$ \\
\hline & Management & 28 & $9.9 \%$ & 13 & $14.8 \%$ & 41 & $11.0 \%$ \\
\hline & Other & 15 & $5.3 \%$ & 10 & $11.4 \%$ & 25 & $6.7 \%$ \\
\hline \multirow{2}{*}{$\begin{array}{l}\text { Stage } \\
\text { degree }\end{array}$} & Second year & 174 & $61.3 \%$ & 18 & $20.5 \%$ & 192 & $1.6 \%$ \\
\hline & Third year & 110 & $38.7 \%$ & 64 & $72.7 \%$ & 174 & $51.6 \%$ \\
\hline \multirow{3}{*}{$\begin{array}{l}\text { Employment } \\
\text { status }\end{array}$} & Not working $(0)$ & 44 & $15.5 \%$ & 26 & $29.5 \%$ & 70 & $46.8 \%$ \\
\hline & Working part-time & 164 & $57.7 \%$ & 36 & $40.9 \%$ & 200 & $18.8 \%$ \\
\hline & Working full-time & 76 & $26.8 \%$ & 26 & $29.5 \%$ & 102 & $53.8 \%$ \\
\hline \multirow{4}{*}{$\begin{array}{l}\text { Months with } \\
\text { employer }\end{array}$} & Less than 6 months & 44 & $17.5 \%$ & 11 & $14.9 \%$ & 55 & $5.8 \%$ \\
\hline & Between 6 and 12 months & 35 & $13.9 \%$ & 29 & $39.2 \%$ & 64 & $16.9 \%$ \\
\hline & Between 1 and 2 years & 53 & $21.1 \%$ & 26 & $35.1 \%$ & 79 & $19.7 \%$ \\
\hline & More than 2 years & 119 & $47.4 \%$ & 8 & $10.8 \%$ & 127 & $24.3 \%$ \\
\hline \multirow{3}{*}{$\begin{array}{l}\text { Size of } \\
\text { organisation }\end{array}$} & $1-49$ (small) & 105 & $42.0 \%$ & 19 & $25.7 \%$ & 124 & $39.1 \%$ \\
\hline & 50 - 149 (medium) & 47 & $18.8 \%$ & 9 & $12.2 \%$ & 56 & $38.3 \%$ \\
\hline & 150+ (large) & 98 & $39.2 \%$ & 46 & $62.2 \%$ & 144 & $17.3 \%$ \\
\hline \multirow[t]{3}{*}{ Sector } & Public sector & 81 & $32.4 \%$ & 18 & $24.3 \%$ & 99 & $44.4 \%$ \\
\hline & Private sector & 149 & $59.6 \%$ & 54 & $73.0 \%$ & 203 & $62.7 \%$ \\
\hline & Not-for-profit & 20 & $8.0 \%$ & 2 & $2.7 \%$ & 22 & $6.8 \%$ \\
\hline
\end{tabular}

\section{Instrument.}

Demographic and background characteristic measures. Survey participants initially answered questions on the demographic, background and employment characteristics summarised in Table 1. 
Career orientation measures. The questionnaire then sought responses to questions reflecting the twenty seven items developed by Briscoe and Hall (2005) to gauge an individual's position on the continua for protean and boundaryless career attitudes. The Protean Career Attitudes Scale, comprising 14 items, was used to measure self-directed and values-driven career management dimensions and the Boundaryless Career Attitude Scale, comprising 13 items, was used to measure boundaryless mindset and physical mobility. Candidates were asked to indicate the extent to which the items were true for them. A five point rating scale was used with a negative anchor of 'to little or no extent' (1) and positive anchor of 'to a great extent' (5). The 27-item scale has been used in a number of more recent studies (for example, Briscoe et al., 2006; Hall, Kossek, Briscoe, Pichler \& Lee, 2013).

\section{Statistical analysis.}

Data were analysed in two parts. First, an exploratory factor analysis of the career attitude scales, descriptive statistics, and bivariate correlations among measured variables were conducted. Second, hierarchical multiple regression models were tested to address hypotheses relating to influences on career attitudes. Analysis was conducted using SPSS 22.0. Prior to analysis, mean differences in the career attitudes of Business undergraduates in the UK and Australia were analysed with none reported. Measurement and structural invariance was also computed to ensure the equivalence of the survey instrument and comparability for the UK and Australian samples. Factor structures were confirmed for both samples individually and the combined sample with item-factor loadings ranging from .31 to .94 across all measured variables. Invariance was demonstrated and the samples combined. For the hierarchical analysis, dummy variables were created for gender, institution, degree specialisation and employment status. Base variables are marked with (0) in Table 1. 


\section{Diagnostic analysis.}

Preliminary analysis of the continuous predictor variable, age, indicated normality with measures of kurtosis and skewness within 'normal limits', less than 10 and 5 respectively (see Curran, West \& Finch, 1996).

\section{Results}

\section{Career attitudes among undergraduates.}

Exploratory Factor Analysis was performed on the protean and boundaryless career attitude scales using Principal Axis Factoring (PAF) and direct oblimen rotation. EFA was used given the purpose of evaluating the constructive validity of established scales and 'proving' the proposed theory of four dimensions (see Williams, Brown \& Onsman, 2012). PAF is a commonly used extraction method, along with Principal Components Analysis (PCA). Debate on the selection of which method is ongoing yet Thompson (2004) argues there is little difference when measures demonstrate high reliability. Direct oblimin rotation was used due to the expectation for correlated factors.

For the protean attitudes scale, a three factor solution emerged, yet the scree plot indicated a two factor model was appropriate. Scree analysis was used for ease and a two factor solution was clearly visible. Further analysis of how many factors to extract using, for example, parallel analysis was not deemed necessary. Restriction to a two factor solution produced the pattern matrix presented in Table 2. The eigenvalue for the first factor, selfdirection, was 4.38 and counts for $31 \%$ of the explained variance. The eigenvalue for the second factor, values-driven, was 1.76 and counts for $13 \%$ of the explained variance. KMO measure of sampling adequacy was .86, above the recommended value of 0.6 (Pallant, 2005, p. 182), and Bartlett's test of sphericity was significant $(p<.001)$. The final item in the self- 
direction dimension - 'In the past I have relied more on myself than others to find a new job when necessary' - was removed from the analysis due to its low factor loading. Removing it also increased the reliability of the self-direction dimension. Also problematic was the values driven item, 'What's most important to me is how I feel about my career success, not how other people feel about it'. This not only produced a relatively low factor loading but there was some evidence of cross-loading onto self-direction, leading to the item being removed. Again, removing the item increased the reliability score for the dimension. The final rotated pattern matrix is presented in Table 3. The eigenvalue for the first factor, self-direction, was 4.03 and counts for $35 \%$ of the explained variance. The eigenvalue for the second factor, values-driven, was 1.76 and counts for $15 \%$ of the explained variance. The correlation between the two factors obtained was .433.

Table 2 Protean career attitude scales (see Briscoe et al. 2006)

\begin{tabular}{|c|c|c|c|}
\hline Dimension & e & $\begin{array}{c}\text { Factor } \\
1\end{array}$ & $\begin{array}{c}\text { Factor } \\
2\end{array}$ \\
\hline \multirow[t]{8}{*}{$\begin{array}{l}\text { Self- } \\
\text { direction }\end{array}$} & $\begin{array}{l}\text { When development opportunities have not been offered by my } \\
\text { company, I've sought them out on my own. }\end{array}$ & .34 & .01 \\
\hline & I am responsible for my success or failure in my career. & .55 & -.04 \\
\hline & Overall, I have a very independent, self-directed career. & .65 & .02 \\
\hline & $\begin{array}{c}\text { Freedom to choose my own career path is one of my most important } \\
\text { values. }\end{array}$ & .55 & .06 \\
\hline & I am in charge of my own career. & .77 & -.08 \\
\hline & Ultimately, I depend upon myself to move my career forward. & .70 & -.09 \\
\hline & Where my career is concerned, I am very much "my own person. & 62 & .07 \\
\hline & $\begin{array}{l}\text { In the past I have relied more on myself than others to find a new } \\
\text { job when necessary [item removed]. }\end{array}$ & .20 & .15 \\
\hline \multirow[t]{6}{*}{$\begin{array}{l}\text { Values- } \\
\text { driven }\end{array}$} & $\begin{array}{c}\text { I navigate my own career, based on my personal priorities, as } \\
\text { opposed to my employer's priorities. }\end{array}$ & .25 & .47 \\
\hline & $\begin{array}{l}\text { It doesn't matter much to me how other people evaluate the choices } \\
\text { I make in my career }\end{array}$ & .18 & .43 \\
\hline & $\begin{array}{l}\text { What's most important to me is how I feel about my career success, } \\
\text { not how other people feel about it [item removed]. }\end{array}$ & .31 & .27 \\
\hline & $\begin{array}{l}\text { I'll follow my own conscience if my company asks me to do } \\
\text { something that goes against my values. }\end{array}$ & -.04 & .71 \\
\hline & $\begin{array}{l}\text { What I think about what is right in my career is more important to } \\
\text { me than what my company thinks. }\end{array}$ & -.09 & .76 \\
\hline & $\begin{array}{l}\text { In the past I have sided with my own values when the company has } \\
\text { asked me to do something I don't agree with. }\end{array}$ & -.05 & .63 \\
\hline
\end{tabular}


Table 3 Boundaryless and protean career attitude scales (see Briscoe et al. 2006)

\section{Protean career attitudes}

Selfdirection

Valuesdriven

Boundaryless mindset

Physical mobility*
When development opportunities have not been offered by my company, I've sought them out on my own.

I am responsible for my success or failure in my career.

Overall, I have a very independent, self-directed career.

Freedom to choose my own career path is one of my most important values.

I am in charge of my own career.

Ultimately, I depend upon myself to move my career forward.

Where my career is concerned, I am very much "my own person.

$.698-.073$

I navigate my own career, based on my personal priorities, as opposed to my employer's priorities.

$.610 \quad .081$

It doesn't matter much to me how other people evaluate the choices I make in my career

I'll follow my own conscience if my company asks me to do something that goes against my values.

$.177 \quad .396$

$-.036 \quad .705$

What I think about what is right in my career is more important to me than what my company thinks.

In the past I have sided with my own values when the company has asked me to do something I don't agree with.

\section{Boundaryless career attitudes}

I seek job assignments that allow me to learn something new

I would enjoy working on projects with people across many

organizations.

I enjoy job assignments that require me to work outside of the organization

I like tasks at work that require me to work beyond my own department.

I enjoy working with people outside of my organization.

I enjoy jobs that require me to interact with people in many different organizations.

$\begin{array}{llll}\text { I have sought opportunities in the past that allow me to work } & .55 & -.18\end{array}$ outside the organization.

I am energized in new experiences and situations.

I like the predictability that comes with working continuously for the same organization.

\section{I would feel very lost if I couldn't work for my current} organization.

I prefer to stay in a company I am familiar with rather than look for employment elsewhere.

If my organization provided lifetime employment, I would never desire to seek work in other organizations.

If my ideal career I would work for only one organization. 
The boundaryless career attitudes produced two clean factors (see the rotated pattern matrix in Table 2) in alignment with Briscoe et al.'s (2006) development and testing of the scale. The eigenvalue for the first factor, boundaryless mindset, was 4.56 and counts for $35 \%$ of the explained variance. The eigenvalue for the second factor, values-driven, was 2.88 and counts for $28 \%$ of the explained variance. KMO measure of sampling adequacy was .86 and Bartlett's test of sphericity was significant $(p<.001)$. See Table 3 for the rotated pattern matrix. The correlation between the two obtained factors was .022 .

The means, standard deviations, Cronbach alpha scores and correlations of variables are presented in Table 4. Discrimant validity was evidenced with variables we would expect to be correlated observed as such and the absence of correlations among variables we would not expect to be related. Results indicated the students score more highly, on average, in selfdirection, closely followed by the boundaryless mindset dimension. Physical mobility achieved the lowest mean rating and most variability with the highest recorded standard deviation. Its mean is not dissimilar from the values driven dimension and, in support of hypotheses $1 \mathrm{a}$ and $1 \mathrm{~b}$, the 'high-low' pattern among the two items that constitute each of the protean and boundaryless career attitude scales was confirmed. Here, the mean rating for selfdirection was higher than for values-driven, and Briscoe and Hall's (2006) 'reactive' career profile is confirmed, and the mean rating for boundaryless mindset is higher than physical mobility, confirming Sullivan and Arthur's (2006) quadrant three career profile. 
Table 4 Descriptive statistics and correlations $(N=372)$

\begin{tabular}{|c|c|c|c|c|c|c|c|c|c|c|c|c|c|c|c|c|c|}
\hline Variable & $M$ & $S D$ & $\alpha$ & 1 & 2 & 3 & 4 & 5 & 6 & 7 & 8 & 9 & 10 & 11 & 12 & 13 & 14 \\
\hline 1. Age & 25.15 & 7.09 & & & & & & & & & & & & & & & \\
\hline 2. Gender & & & & -.02 & & & & & & & & & & & & & \\
\hline $\begin{array}{l}\text { 3. Specialisation: } \\
\text { Tourism }\end{array}$ & & & & -.08 & .02 & & & & & & & & & & & & \\
\hline $\begin{array}{l}\text { 4. Specialisation: } \\
\text { Marketing }\end{array}$ & & & & $-.18^{* *}$ & .10 & $-.16^{* *}$ & & & & & & & & & & & \\
\hline $\begin{array}{l}\text { 5. Specialisation: } \\
\text { HRM }\end{array}$ & & & & .02 & .08 & $-.14^{* *}$ & $-.19^{* *}$ & & & & & & & & & & \\
\hline $\begin{array}{l}\text { 6. Specialisation: } \\
\text { Generalist }\end{array}$ & & & & -.08 & -.03 & $-.14^{* *}$ & $-.19^{* *}$ & $-.16^{* *}$ & & & & & & & & & \\
\hline $\begin{array}{l}\text { 7. Specialisation: } \\
\text { Management }\end{array}$ & & & & -.05 & -.09 & $-.12^{*}$ & $-.16^{* *}$ & $-.14^{* *}$ & $-.14^{* *}$ & & & & & & & & \\
\hline $\begin{array}{l}\text { 8. Specialisation: } \\
\text { Other }\end{array}$ & & & & .09 & $-.14^{* *}$ & -.10 & $-.13^{*}$ & $-.11^{*}$ & $-.11^{*}$ & -.09 & & & & & & & \\
\hline $\begin{array}{l}\text { 9. Employment } \\
\text { status: Working } \\
\text { PT }\end{array}$ & & & & $-.21^{* *}$ & .09 & .07 & -.02 & .00 & -.04 & -.02 & -.05 & & & & & & \\
\hline $\begin{array}{l}\text { 10. Employment } \\
\text { status: } \quad \text { Working } \\
\text { FT }\end{array}$ & & & & $.20^{* *}$ & -.05 & -.08 & -.02 & .08 & .01 & .05 & .00 & $-.66^{* *}$ & & & & & \\
\hline 11. Self-direction & 4.03 & .56 & .78 & .00 & .01 & -.08 & .10 & .03 & -.01 & .06 & -.04 & .08 & .05 & & & & \\
\hline 12. Values-driven & 3.48 & .75 & .78 & .06 & -.05 & -.02 & -.10 & .06 & .00 & $.12^{*}$ & -.01 & $.10^{*}$ & .07 & $.40^{* *}$ & & & \\
\hline $\begin{array}{l}\text { 13. Boundaryless } \\
\text { mindset }\end{array}$ & 4.00 & .69 & .88 & -.03 & .08 & -.04 & .08 & .10 & .07 & .02 & -.03 & -.01 & .10 & $.44^{* *}$ & $.20^{* *}$ & & \\
\hline $\begin{array}{l}14 . \quad \text { Physical } \\
\text { mobility }\end{array}$ & 3.43 & .91 & .81 & .02 & -.03 & -.06 & $.14^{* *}$ & -.05 & -.04 & .01 & -.02 & -.02 & .10 & .07 & -.01 & .02 & \\
\hline 15. Institution & & & & $-.27^{* *}$ & $-.10^{*}$ & $-.20^{* *}$ & $.19^{* *}$ & $-.13^{*}$ & $.24^{* *}$ & .07 & $.10^{*}$ & $-.14^{* *}$ & .03 & -.03 & -.09 & .03 & $.21^{* *}$ \\
\hline
\end{tabular}




\section{Relationship among protean and boundaryless career attitudes.}

The pattern of significant correlations among the four career attitude dimensions replicated those for undergraduates in Briscoe et al.'s (2006) study and Hypotheses 2a, 2b, $2 \mathrm{c}$, and $2 \mathrm{~d}$ are supported. There was a positive, significant correlation between the selfdirection and values driven dimensions within protean career attitudes and the self-direction dimension was positively correlated to the boundaryless mindset dimension. Similarly, values-driven was positively correlated with boundaryless mindset. Finally, the physical mobility dimension was not significantly correlated with any of the other three dimensions.

\section{Influence of individual characteristics.}

The results of the hierarchical multiple regression exploring the extent of protean and boundaryless career attitudes is presented in Table 5. Two models were generated for each of the four dimensions of career attitudes. Institution was entered in the first step to isolate any influence pertaining to university type/location on the four dimensions. This was deemed important given that the sample comprises students from both UK and Australian universities. The second step assessed the influence of background characteristics on each dimension. There was no evidence of multicollinearity, with VIF ranging between 1.05 and 1.91 and, therefore, within the recommended threshold (Hair, Black, Babin \& Anderson, 2010). 
Table 5 Hierarchical multiple regression results for protean and boundaryless career attitudes

\section{Protean}

\section{Self-direction Values-driven Boundaryless Physical mobility mindset}

Model $1 \quad$ Model $2 \quad$ Model $1 \quad$ Model $2 \quad$ Model $1 \quad$ Model $2 \quad$ Model $1 \quad$ Model 2

\begin{tabular}{|c|c|c|c|c|c|c|c|c|c|}
\hline $\begin{array}{l}\text { Step 1: } \\
\text { variable } \\
\text { Institution }\end{array}$ & Control & -.01 & -.02 & -.09 & -.07 & .03 & .00 & $.21 * *$ & $.26 * *$ \\
\hline \multicolumn{10}{|c|}{$\begin{array}{l}\text { Step 2: Background } \\
\text { characteristics }\end{array}$} \\
\hline Age & & & .04 & & .05 & & .01 & & .09 \\
\hline Gender & & & -.02 & & -.06 & & .07 & & -.02 \\
\hline Tourism & & & -.05 & & .01 & & .06 & & -.01 \\
\hline Marketing & & & $.15^{*}$ & & -.01 & & $.18^{* *}$ & & .08 \\
\hline HRM & & & .05 & & .07 & & $.17 * *$ & & -.04 \\
\hline Generalist & & & .07 & & .06 & & $.17 * *$ & & -.09 \\
\hline Management & & & .08 & & $.14^{*}$ & & .11 & & -.03 \\
\hline Other & & & .00 & & .03 & & .06 & & -.05 \\
\hline $\begin{array}{l}\text { Employment } \\
\text { Working PT }\end{array}$ & status: & & $.24 * *$ & & $.26^{* *}$ & & .11 & & $.15^{*}$ \\
\hline $\begin{array}{l}\text { Employment } \\
\text { Working FT }\end{array}$ & status: & & $.18^{*}$ & & $.21^{* *}$ & & $.16^{*}$ & & $.18^{* *}$ \\
\hline$F$-value & & .05 & $2.06^{*}$ & 3.03 & $2.62 * *$ & .435 & $2.157^{*}$ & $17.27 * *$ & $3.24 * *$ \\
\hline$R^{2}$ & & .00 & .06 & .01 & .07 & .00 & .06 & .05 & .09 \\
\hline Adjusted $R^{2}$ & & .00 & .03 & .01 & .05 & .00 & .03 & .04 & .06 \\
\hline$\Delta R^{2}$ & & & .06 & & .07 & & .06 & & .05 \\
\hline
\end{tabular}

Notes: ${ }^{*} p<.05 ; * * p<.01$

Institution was not a significant predictor for either dimension of protean career attitudes or boundaryless mindset. It did, however, predict physical mobility, explaining 5\% of variance in the first model for this dimension. For protean career attitudes, background characteristics represent significant sets of predictor variables for both the values driven and self-direction dimensions. Using $R^{2}$, background characteristics explained $6 \%$ of variance for self-direction and $7 \%$ of variance for values driven. These low variance regression models for both boundaryless and protean career are common to other studies on career attitudes (see, for example, Segers et al., 2008). Background characteristics also significantly predicted both dimensions of boundaryless career attitudes. The standardised regression coefficients for individual variables are presented in each model. For $R^{2}$, they explained $6 \%$ of variance for boundaryless mindset and $9 \%$ for physical mobility. 
There was no evidence of an age or gender effect for protean and boundarylesss career attitudes, supporting hypotheses $3 \mathrm{a}, 3 \mathrm{~b}, 4 \mathrm{a}$, and $4 \mathrm{~b}$ are supported. Hypothesis $3 \mathrm{~b}$, that age is positively associated with values-driven, was not supported.. There was evidence for the influence of employment status on career attitudes with both hypotheses $5 \mathrm{a}$ and $5 \mathrm{~b}$ partially supported. There was a consistent positive effect for those working part-time or fulltime on both of the protean career attitude dimensions, apart from full-time work on selfdirection. The positive effect was relatively stronger for protean career attitudes and moderately stronger for those working part-time than full-time. The influence of employment status was slightly less pronounced for boundaryless career attitudes and, conversely, the effect was relatively stronger for those working full-time. A positive, significant effect was recorded for both full-time and part-time working on physical mobility. For those working full-time, employment status had a positive significant effect on boundaryless mindset.

In relation to hypothesis $6 \mathrm{a}$, the data only partially supported the influence of business degree specialisation on protean career attitudes. Significant results were recorded for the Marketing sub-group on self-direction and Management sub-group on values driven, both scoring significantly higher in relation to the base sub-group of Finance and Accounting. For boundaryless mindset, hypothesis $6 \mathrm{~b}$ was also partially supported with a positive effect for the Marketing, Generalist, and HRM. Overall, for all variables, the effect sizes were fairly moderate with significant results ranging from .14 to .26 across both protean and boundaryless attitudes.

\section{Discussion/Implications}


HEIs are responsible for ensuring students are cognisant of the challenges of the contemporary labour market and are sufficiently flexible and resilient in their outlook to cope with both complexity and change. Given the association between career attitudes and both work performance and career success, understanding such orientations among potential recruits and employees should lie at the heart of effective talent management. Understanding and developing orientations has implications for the 'career proposition' being sold to prospective employees, the means and criteria by which new recruits are selected and how employees are managed for both performance and retention.

\section{Career attitudes among Business undergraduates.}

Briscoe et al. (2012) suggest that as "protean and boundaryless orientations are considered attitudinal, they can be taught and learned" (p. 36). The findings presented here therefore have the potential to inform organisations as to where to concentrate their efforts for structured graduate development programs and/or ongoing professional development opportunities for incoming graduate recruits. Moreover, reflecting this viewpoint, HEIs have a crucial role to play in shaping career predisposition, either through reinforcement or encouraging adaptation, to be commensurate with that required for success whether in the graduate labour market generally or in a particular occupational or sectoral field. Consequently, the findings have important implications for curriculum and pedagogic development in higher education conducive to the development of independent, proactive, agentic, open-minded, and self-reflective graduates.

Consideration should be given, however, by professional and education practitioners and stakeholders more broadly - as to whether developing protean and boundaryless career attitudes are preferable in all students and incoming graduate recruits. Fostering protean 
attitudes appears critical for graduates to successfully navigate a sustainable career pathway amid flat organisational structures, contract working and soft labour markets. While boundaryless attitudes may provide more opportunities for individuals seeking career success, what does it mean for the productivity and efficiency of organisations already managing the significant movement of graduates between jobs (see Abreu, Faggian \& McCann, 2015)? Perhaps developing elements of the four dimensions yet still promoting organisational career management will better meet the needs of individuals, organisations and the nation's economy. Given the interrelated nature of boundaryless and protean career attitudes, developing one, without the other, does not appear feasible. It is the responsibility of stakeholders to foster an appreciation of and opportunities for both effective career selfmanagement and organisational career management for emerging professionals.

The correlation between self-direction and boundaryless mindset is not surprising. Arguably, the self-reliance and independent decision-making denoted by high levels of 'selfdirectedness' are the psychological foundations upon which the proactive establishment of networks to facilitate career success are based. The relatively high scores in both dimensions is a positive result and resonate with those of previous research which suggest, at least, the internalisation of the rhetoric of the new career reality if not the adoption of commensurate career orientations (King, 2003; 2004). The finding that undergraduates nearing the completion of their degree display clear preference for self-direction and recognise the value of networks has significance for key stakeholders in the graduate labour market. For HEIs, an appreciation of dominant career attitudes among undergraduates would allow for more nuanced preparation of students for graduate employment. That undergraduates exhibit attitudes associated with 'new' careers, such as self-directedness and a boundaryless mindset, provides an opportunity to develop associated abilities in environmental scanning, 
independent decision-making, and networking that enable the effective enactment of such orientations.

For employers, the high levels of self-direction and boundaryless mindset among current students may be concerning given the assumption that these attitudes produce diminished organisational commitment among employees (see Çakmak-Otluoğlu, 2012). There is, however, mixed evidence of a negative association between self-direction and boundaryless mindset with organisational commitment (Briscoe \& Finkelstein, 2009), important given the link between commitment and actual and intended labour turnover (Çakmak-Otluoğlu, 2012). To ensure both individual career success and organisational effectiveness, best practice in managing individuals who demonstrate higher levels of selfdirection and boundaryless mindset should focus on cultivating an organisational culture of flexibility through practices such as job rotation, short-term projects, and opportunities for virtual, internal and external networking (Clarke, 2009). Individuals with self-direction and boundaryless mindset are more likely to engage in the career development behaviours of seeking external relationships, active coping, and identity awareness, even during periods of economic downturn (Briscoe et al., 2012). These behaviours, to differing degrees, may ultimately lead to greater well-being, better performance at work, more effective job searching, and enhanced career success (Briscoe et al., 2012). The benefits, therefore, prevail at both an individual and organisational level.

The relatively low levels of values driven attitudes may be explained by the sample predominantly comprising young people at the outset of career and, therefore, may not yet have a clear sense of their values in relation to work and employment. The 'high-low' phenomenon for self-direction and values driven confirms Briscoe and Hall's (2006) 
'reactive' profile among undergraduates. This is of concern and emphasises the importance of career development learning, by both universities and graduate employers, as students "would not ultimately have the perspective to guide his or her own career sufficiently" (Briscoe \& Hall, 2006, p. 8). The importance of developing the values-driven dimension draws on the notion of fostering a 'healthy self-concept' (Stewart \& Knowles, 1999) and 'graduate identity' (Holmes, 2013) during university as the basis for effective career decision-making. It suggests a clear need for HEIs to support students in better understanding motives, values and attitudes. Higher education plays a vital role in socialising students in professional philosophy (see Trede, Macklin \& Bridges, 2012) and is critical for new graduates to transfer new skills and knowledge successfully without culture shock (see Reid, Dahlgren, Petoczm \& Dahlgren, 2008). The formation of a positive graduate, or preprofessional, identity is associated with career success (Purcell et al., 2013), thus it would be deficient of HEIs to fail to seek to adequately equip graduates with particular attitudes particularly where they increasingly form 'desirable' criteria for appointment to graduate roles. In regard to enhancing values driven attitudes among undergraduates, industry collaboration with HEIs is critical. For instance, Work-Integrated Learning (WIL) initiatives, such as internships, client-based projects, case studies and practicums, are important ways of exposing undergraduates to professional ideology, values and beliefs (West \& Chur-Hansen, 2004). They also offer a valuable opportunity for students to evaluate their personal values and reconcile them with those upheld in their intended profession (see Trede et al., 2012). As HM Treasury (2006) notes, "we must begin a new journey to embed a culture of learning; employer and individual awareness must increase" (p. 2).

The data indicate that among undergraduates a preference for physical mobility does not correlate with either a protean career orientation or boundaryless mindset. This may 
suggest tentativeness among undergraduates at the outset of their careers, connected to inexperience and lower self-assuredness, regarding the desirability and necessity of mobility. Indeed, it may be expected that mobility preferences tend to be more conservative before the demands of a chosen career are fully known. It also echoes King's (2003) study, albeit among graduates, that despite paying 'lip service' to the new career, there remains a preference for more traditional careers that are less likely to require intra-firm, intra-sectoral or geographic mobility. As such, physical mobility should not necessarily be used as a primary proxy for

either boundaryless or protean career attitudes among emerging professionals. This finding does, however, contradict the more recent suggestion that graduates demonstrate increasing job mobility, particularly among the international cohort (AUIDF, 2013). The high-low phenomenon for boundaryless mindset and physical mobility, the 'quadrant 3' career profile (Sullivan \& Peter, 2006), could be problematic for undergraduates. The profile suggests a confidence in employability yet this is not complemented with an openness to mobility across occupations, sectors, geographical regions or organisations. As a result, students could become isolated in their future job roles, jeopardising their ability for career growth.

\section{Influence of individual characteristics.}

Perhaps the most notable finding with respect to the influence of background characteristics on career orientation is the influence of degree specialisation. The positive associations with boundaryless mindset of the Marketing, HRM, and the Generalist subgroups, in contrast to the Finance and Accounting base group, may reflect their less technical nature of their degree programs and the less specific relationship between higher education and employment in these occupations. We might speculate that the relationship between degree subject choice and the adoption of particular career orientations is mediated by the relationship between subject of study and intended career. The more 'bounded' or specific the 
intended occupation, the lowered likelihood of internalising attitudes associated with the boundaryless career. The more values driven attitude among the Management sub-group may be accounted for by the increasing focus on business ethics, corporate responsibility and sustainability in management curriculum in recent years, as well as some internalisation of messages within the employability discourse and the value in developing self-knowledge. High levels of self-direction among the Marketing sub-group might be attributed to their enhanced participation in extra-curricular activities - including informal internships and volunteering at community events. This may be partially due to a greater number of opportunities available in their field than for the Finance and Accounting base group. These variations by degree specialisation highlight to both HEIs and employers that different student groups require careers support in different ways.

The most significant influence was found to be between employment status and career orientation, particularly the significantly lower scores in all four dimensions among those not working at the time of the survey. This may reflect the fact that ongoing work experience reinforces the adoption of particular attitudes and exposure to the realities of work and the workplace tend to manifest in a stronger propensity towards career orientations that are commensurate with contemporary employment. This finding highlights the importance of undergraduates gaining work experience during their academic studies (see Reid et al., 2008). Relevant work experience - through part-time employment (see Greenbank, Hepworth \& Mercer, 2009) or WIL activities (Cornelissen \& Van Wyk, 2007) - can improve a student's understanding and connection with their intended profession. It also provides students with an insight into their chosen discipline or function and the antecedents of success within their field of activity. HEIs and employers can enhance work experience for undergraduates through greater collaboration on opportunities such as cadetships, vacation programs, and 
internships, as well as actively promoting part-time work opportunities through online career management portals or university learning management systems.

Interestingly, demographic variables were not found to be significantly related to differences in orientation, despite their presence in previous studies, suggesting further exploration in this area is required. The data do not suggest that, whilst malleable, these orientations necessarily develop with age. This might be explained by the fact that whilst diverse in age and prior employment experience, respondents in our sample were at the same stage in their 'educational' career and, therefore, more likely to share common orientations commensurate with their undergraduate status, thus limiting the age effect. Gender was not found to be a significant influence on the adoption of orientations. It may be that the influence of the partner's career on one's own attitudes, detected in previous studies (Clarke, 2009; Forett et al., 2010), is less apparent in this relatively young sample. Individuals, along with their partners, are largely at the stage of entering their profession and are less likely to have carer responsibilities. The potential influence of partners' careers on an individual's career attitudes, and the moderating influence of age and career stage, highlights an interesting area for future research. In relation to variations by institution, students in the UK reported a more favourable attitude to physical mobility than their Australian counterparts. This could perhaps be explained by the widely accepted practice of undergraduates relocating for their studies in comparison to undergraduates in Australia who are more likely to remain in their home cities during their studies and are therefore less predisposed to the notion of relocation at the time of the survey.

\section{Limitations and future research}

While this study contributes to our understanding of career attitudes among undergraduates, a number of limitations are acknowledged. In alignment with Briscoe et al.'s 
(2006) study (Gerber et al., 2009), we do not evaluate the more traditional career orientation among respondents, in particular whether in fact one orientation substitutes another and in which career contexts this may occur. Further, the study relies on the self-reporting of career attitudes (Douglas et al., 2012). While student perceptions matter, an alternative approach could be objective assessment by career management providers in the university setting. Further, collecting data using one survey raises concerns with common method variance (Podsakoff, MacKenzie, Lee \& Podsakoff, 2003). Finally, the inclusion of additional control variables which could tease out the employment history of the undergraduate sample would enhance our understanding of the precise influence of working prior to and during one's studies - in addition to WIL - on career orientations. An additional area of future research would be developing our understanding of the 'types' of protean and boundaryless profiles, among undergraduates or other samples, using cluster analysis. This could provide rich insight into how the four different elements interact and align with each other and could be conducted using latent class analysis and latent profile analysis, or finite mixture modelling.

It is also important to note the potential limitations of this research associated with the sample under analysis. Both institutions that participated in this study are newer HEIs in their respective markets specialising in vocational or semi-vocational education and with clear strategic focus on preparing undergraduates for the labour market. As such, the 'employability' message - that career success is largely predicated upon individual adaptability, pro-activity and responsibility - is strongly communicated. It is perhaps, therefore, unsurprising that students report back the rhetoric of this discourse in discussing their personal orientations, a tendency which would be less marked for undergraduates in different institutions with less explicit emphasis given to preparation for employment. 
Similarly, it might be the case that undergraduates of other disciplines might display lesser propensity towards new career orientations.

\section{Conclusion}

The emerging importance of self-managing one's career, particularly for job attainment and career success (De Vos \& Soens, 2008), prompted this study of protean and boundaryless career attitudes among undergraduates. Intensely competitive graduate labour markets, and evidence of comparatively high levels of underemployment and unemployment among graduates in developed economies, reinforce the need for undergraduates to engage with the new career concept and to take responsibility for their own careers even prior to entering the labour market. In this regard, the findings presented here are mixed - selfdirection and boundaryless mindset dimensions reporting relatively high mean ratings yet notably weaker averages for physical mobility and the values driven dimension. This 'highlow pattern' for the constituent dimensions of both protean and boundaryless career attitudes raises questions as to how higher education practitioners can work with students to nurture more positive protean and boundaryless career attitudes and what these deficiencies may imply for industry. Students based in the UK reported a more positive attitude regarding physical mobility and there were some differences for both protean and boundaryless attitudes across the discipline groupings. Employment status appeared to influence career attitude dimensions the most, with more positive attitudes reported among those undergraduates currently working. 


\section{References}

Abreu, M., Faggian, A., \& McCann, P. (2015). Migration and inter-industry mobility of UK graduates. Journal of Economic Geography, 15(2), 353-385. DOI/10.1093/jeg/lbt043

Adamson, S., Doherty, N. \& Viney, C. (1998). The meanings of career revisited: Implications for theory and practice. British Journal of Management, 9(4), 251-9. DOI: 10.1111/14678551.00096

Arthur, M. (1994). The boundaryless career: A new perspective for organizational enquiry. Journal of Organisational Behaviour, 15(4), 295-306. DOI/10.1002/job.4030150402.

AUIDF (2013). Improving the employment outcomes of international students. Melbourne, Australia: Australian Universities International Directors' Forum.

Baruch, Y. (2004). Transforming careers: from linear to multidirectional career paths: Organizational and individual perspectives. Career Development International, 9(1), 58-73. DOI/10.1108/13620430410518147

Baruch, Y. (2006). Career development in organisations and beyond: balancing traditional and contemporary viewpoints. Human Resource Management Review, 16(2), 125-138. DOI/10.1016/j.hrmr.2006.03.002

Bennett, J., Pitt, M., \& Price, S. (2012). Understanding the impact of generational issues in the workplace. Facilities, 30(7), 278-288. DOI/10.1108/02632771211220086

Briscoe, J., \& Hall, D. (2005). Protean and boundaryless career assessment collection. Boston, MA: Unpublished, copyrighted scale collection.

Briscoe, J., \& Hall, D. (2006). The interplay of boundaryless and protean careers: Combinations and implications. Journal of Vocational Behavior, 69(1), 4-18. DOI/10.1016/j.jvb.2005.09.002.

Briscoe, J., Hall, D., \& DeMuth, R. (2006). Protean and boundaryless careers: An empirical exploration. Journal of Vocational Behavior, 69(1), 30-47. DOI/10.1016/j.jvb.2005.09.003.

Briscoe, J., Henagan, S., Burton, J., \& Murphy, W. (2012). Coping with an insecure employment environment: The differing roles of protean and boundaryless career orientations. Journal of Vocational Behavior, 80(2), 308-316. DOI/10.1016/j.jvb.2011.12.008.

Briscoe, J., \& Finkelstein, L. (2009). The 'new career' and organizational commitment: Do boundaryless and protean attitudes make a difference? Career Development International, 14(3), 242-260. DOI/10.1108/13620430910966424

Çakmak-Otluoğlu, K. (2012). Protean and boundaryless career attitudes and organizational commitment: The effects of perceived supervisor support. Journal of Vocational Behavior, 80(3), 638-646. DOI/10.1016/j.jvb.2012.03.001

Cohen, L., \& Mallon, M. (1999). The transition from organisational employment to portfolio working: Perceptions ofboundarylessness'. Work, Employment \& Society, 13(2), 329-352.

DOI/10.1177/09500179922117962

Clarke, M., \& Patrickson, M. (2008). The new covenant of employability. Employee Relations, 30(2), 121-141. DOI/10.1108/01425450810843320

Clarke, M. (2009). Plodders, pragmatists, visionaries and opportunists: career patterns and employability. Career Development International, 14(1), 8-28. DOI: 10.1108/13620430910933556.

Cornelissen, J. \& Van Wyk, A. (2007). Professional socialisation: An influence on professional development and role definition. South African Journal of Higher Education, 21(7), 826-841. DOI/10.1108/13620430910933556 
Creed, P., Macpherson, J., \& Hood, M. (2011). Predictors of new economy career orientation in an Australian sample of late adolescents. Journal of Career Development, 38(5), 369-389. DOI/10.1177/0894845310378504

Cron, W. (1984). Industrial salesperson development: A career stage perspective. Journal of Marketing, 48(4), 41-52. DOI: 10.2307/1251509

Curran, P., West, S. \& Finch, J. (1996). The robustness of test statistics to nonnormality and specification error in confirmatory factor analysis, Psychological Methods, 1(1), 16-29. DOI/10.1037/1082-989X.1.1.16

Currie, G., Tempest, S., \& Starkey, K. (2006). New careers for old? Organizational and individual responses to changing boundaries. The International Journal of Human Resource management 17(4), 755-774. 10.1080/09585190600581733

De Vos, A. \& Soens, N. (2008). Protean attitude and career success: the mediating role of self-management. Journal of Vocational Behavior, 73(3), 449-456. DOI/10.1016/j.jvb.2008.08.007

De Vos, A., Dewettinck, K., \& Buyens, D. (2009) The professional career on the right track: A study on the interaction between career self-management and organizational career management in explaining employee outcomes. European Journal of Work and Organizational Psychology, 18(1), 55-80. 10.1080/13594320801966257

Eby, L., Butts, M., \& Lockwood, A. (2003). Predictors of Success in the era of the boundaryless career. Journal of Organizational Behavior, 24(6), 689-708. DOI: $10.1002 /$ job. 214

GCA (2012). GradStats: Employment and salary outcomes of recent higher education graduates. Melbourne: Graduate Careers Australia.

GCA. (2014). Employment for new graduates. Melbourne Australia: Graduate Careers Australia.

GCA. (2015). Where grads go. Melbourne Australia: Graduate Careers Australia.

Gerber, M., Wittekind, A., Grote, G., \& Staffelbach, B. (2009). Exploring types of career orientation: A latent class analysis approach. Journal of Vocational Behavior, 75(3), 303-318. DOI/10.1016/j.jvb.2009.04.003

Greenbank, P., Hepworth, S. \& Mercer, J. (2009). Term-time employment and the student experience. Education + Training, 51(1), 43-55. DOI: 10.1108/00400910910931823.

Greenbank, P. (2011). Improving the process of career decision making: an action research approach. Education + Training, 53(4), 252-266. DOI/10.1108/00400911111138433

Grote, G. \& Raeder, S. (2009) Careers and identity in flexible working: Do flexible identities fare better? Human Relations, 62(2), 219-244. 10.1177/0018726708100358

Hair, J., Black, W., Babin, B. \& Anderson, R. (2010). Multivariate data analysis: A global perspective. New Jersey: Pearson Prentice-Hall.

Hall, D. (1996). Protean careers of the 21st century. Academy of Management Review, 10(4), 8-16. DOI/10.5465/AME.1996.3145315

Hall, D. (2002). Careers in and out of organizations. Thousand Oaks, CA: Sage.

Hall, D. (2004). The Protean career: A quarter-century journey. Journal of Vocational Behavior, 65(1), 1-13. DOI/10.1016/j.jvb.2003.10.006

Hall, D., Kossek, E., Briscoe, J., Pichler, S., \& Lee, M. (2013). Non-work orientations relative to career: A multidimensional measure. Journal of Vocational Behavior, 83(3), 539550. DOI/10.1016/j.jvb.2013.07.005

Herrmann, A., Hirschi, A., \& Baruch, Y. (2015). The protean career orientation as predictor of career outcomes: Evaluation of incremental validity and mediation effects. Journal of Vocational Behavior, 88(1), 205-214. DOI/10.1016/j.jvb.2015.03.008

Hirsh, W. \& Jackson, C. (2004). Managing Careers in Large Organizations. London: The Work Foundation. 
HM Treasury (2006). Leitch review of skills. Prosperity for all in the global economy-world class skills, Final Report. London: HM Treasury.

Holmes, L. (2013). Competing perspectives on graduate employability: possession, position or process? Studies in Higher Education, 38(4), 538-554. 10.1080/03075079.2011.587140 Inkson, K. (2006). Protean and boundaryless careers as metaphors. Journal of Vocational Behavior, 69(1), 48-63. DOI/10.1016/j.jvb.2005.09.004

Inkson, K. Gunz, H., Ganesh, S. \& Roper, J. (2012). Boundaryless Careers: Bringing Back Boundaries. Organization Studies, 33(3), 323-340. DOI/10.1177/0170840611435600

Jain, R., \& Jain, S. (2013). Conceptualization, Measure Development and Empirical Assessment of Career Oriented Attitudes and Employability of Technology Graduates. Vision: The Journal of Business Perspective, 17(2), 143-157. DOI: $10.1177 / 0972262912483528$.

King, Z. (2003). New or traditional careers? A study of UK graduates' preferences. Human Resource Management Journal, 13(1), 5-26. DOI: 10.1111/j.1748-8583.2003.tb00081.x

King, Z. (2004). Career Management: A Guide. London: Chartered Institute of Personnel and Development.

Kuijpers, M. \& Meijers, F. (2012). Learning for now or later? Career competencies among students in higher vocational education in the Netherlands. Studies in Higher Education, 37(4), 449-467. DOI:10.1080/03075079.2010.523144

Leach, J., \& Chakiris, B. (1988). The future of jobs, work and careers. Training and Development Journal, 42(4), 48-54.

Li, I., \& Miller, P. (2013). The absorption of recent graduates into the Australian labour market: Variations by university attended and field of study. Australian Economic Review, 46(1), 14-30. DOI: 10.1111/j.1467-8462.2013.00713.x

Mainiero, L., \& Sullivan, S. (2005). Kaleidoscope careers: An alternate explanation for the “opt-out” revolution. Academy of Management Executive, 19(1), 106-123.

DOI/10.5465/AME.2005.15841962

Mathieu, J., \& Zajac, D. (1990). A review and meta-analysis of the antecedents, correlates and consequences of organizational commitment. Psychological Bulletin, 108(2), 171-194. DOI/10.1037/0033-2909.108.2.171

O'Connell, D., McNeely, E. \& Hall, D. (2008). Unpacking Personal Adaptability at Work. Journal of Leadership \& Organizational Studies, 14(3), 248-259. DOI/10.1177/1071791907311005

Park, Y. (2009). An integrative empirical approach to the predictors of self-directed career management. Career Development International, 14(7), 636-654. DOI/10.1108/13620430911005690

Podsakoff, P., MacKenzie, S., Lee, J., \& Podsakoff, N. (2003). Common Method Biases in Behavioral Research: A Critical Review of the Literature and Recommended Remedies. Journal of Applied Psychology, 88(5), 879-903. DOI/10.1037/0021-9010.88.5.879

Pringle, J., \& Mallon, M. (2003). Challenges for the boundaryless career odyssey. International Journal of Human Resource Management, 14(5), 839-53. DOI: 10.1080/0958519032000080839

Purcell, K., Elias, P., Atfield, G., Behle, H., Ellison, R., \& Luchinskaya, D. (2013).

Transitions into employment, further study and other outcomes. Warwick: Warwick Institute of Employment Research.

Reid, A., Dahlgren, L., Petoczm, P., \& Dahlgren, M. (2008). Identity and engagement for professional formation. Studies in Higher Education, 33(6), 729-742. DOI:10.1080/03075070802457108

Savickas, M. (1997). Career adaptability: An integrative construct for Life-Span, Life-Space Theory. The Career Development Quarterly, 45, 247-259. 
Schneider, B. Smith, D., Taylor, S., \& Fleenor, J. (1998). Personality and organizations: A test of the homogeneity of personality hypothesis. Journal of Applied Psychology, 83(3), 462-470. DOI/10.1037/0021-9010.83.3.462

Segers, J., Inceoglu, I., Vloeberghs, D., Bartram, D., \& Henderickx, E. (2008). Protean and boundaryless careers: A study on potential motivators. Journal of Vocational Behavior, 73(2), 212-230. DOI/10.1016/j.jvb.2008.05.001

Sturges, J. (2008). All in a day's work? Career self-management and the management of the boundary between work and non-work. Human Resource Management Journal, 18(2), 118134. DOI: $10.1111 / \mathrm{j} .1748-8583.2007 .00054 . x$

Sturges, J., Conway, N., Guest, D., \& Liefooghe, A. (2005). Managing the career deal: The psychological contract as a framework for understanding career management, organizational commitment and work behaviour. Journal of Organizational Behaviour, 26(7), 821-838. DOI: $10.1002 /$ job.341

Sullivan, S., \& Arthur, M. (2006). The evolution of the boundaryless career concept: Examining physical and psychological mobility. Journal of Vocational Behavior, 69(1), 1929. DOI/10.1016/j.jvb.2005.09.001

Tams, S. \& Arthur, M. (2007). Studying careers across cultures: Distinguishing international, cross-cultural and globalization perspectives. Career Development International, 12(1), 8698. DOI/10.1108/13620430710724848

Thompson, B. (2004). Exploratory and confirmatory factor analysis: understanding concepts and applications. Washington, DC: American Psychological Association.

Trede, F., Macklin, R., \& Bridges, D. (2012). Professional identity development: a review of the higher education literature. Studies in Higher Education, 37(3), 365-384. DOI:10.1080/03075079.2010.521237

UKCES (2015). Growth through people: Evidence and analysis. Wath-upon-Dearne, UK: UK Commission for Employment and Skills.

Verbruggen, M. (2012). Psychological mobility and career success in the new career climate". Journal of Vocational Behavior, 81(2), 289-297. DOI/10.1016/j.jvb.2011.10.010

West, C., \& Chur-Hansen, A. (2004). Ethical enculturation: The informal and hidden ethics curricula at an Australian medical school. Focus on Health Professional Education, 6(1), 8599.

Williams, B, Brown, T, \& Onsman, A. (2012). Exploratory factor analysis: A five step guide for novices. Australasian Journal of Paramedicine, 8(3), 1-13.

Wilton, N. (2012). Do employability skills really matter in the graduate labour market? The case of business and management graduates. Work, Employment and Society, 25(1), 85-100. DOI/10.1177/0950017010389244 